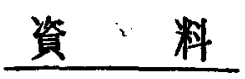

\title{
プラスチックへのメッキ
}

\section{Plating on Plastics}

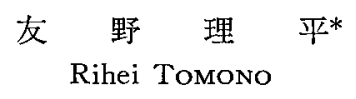

\section{1 はじめに}

プラスチックにメッキする目的は，プラスチックのす ぐれた物性に，金属の寸ぐれた物性を付加することによ り，新しい工業材料を得ようとすることである.

プラスチックにメッキする方法には，いくつかの方法 があるが，工業的に，また商業的に成功しているのは， 化学メッキと電気メッキの併用法である.この方法は, 実用化されてからまだ四年ぐらいの歴史しかないが，基 礎的な研究を待たずに工業化が先行したので，今もなお 問題点を多く残している.

この方法で工業化が進んでいるのは, ABS プラスチ ックだけである. ABS には実用上支障のない程度の密 着のよいメッキが得られるからである. ABS の次に工 業化の予測されるプラスチックはポリプロピレンである が，海外に挍いても，国内においても工業化はいまだ行 なわれていない。

プラスチックにメッキをつけることは容易であるが， 密着のよいメッキをつけることはそれはど容易ではな い.プラスチックにメッキをつける研究の中心は, いか にして密着力を強化するかといらことである. 密着力に は二つの見解があって，一つは機械的な力が主であると するもの，一つは化学的な力が主であるとするものであ るが現状では, 前者が有力で, 今後においても，この考

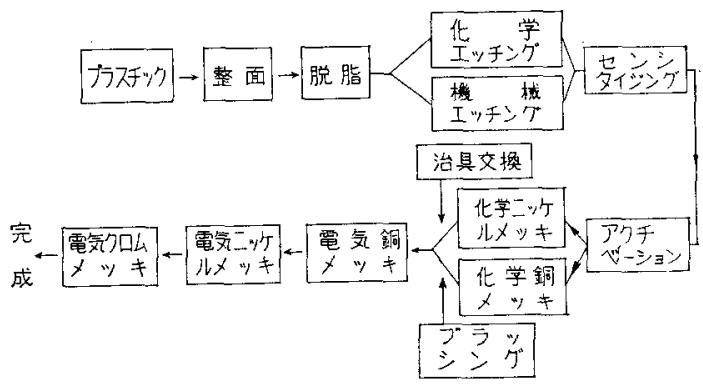

图 1 化学メッキ之電気メッキ学併用したプラスチック メッキ方法の順序 (水洗工程任省略)

\footnotetext{
* 京都府立中小企業総合指導所（京都市下京区西七条名目町） Industrial Reserch Institute Kyoto Prefecture (Nakuracho, Nishi-shichijo, Shimo-kyo-ku Kyoto, Japan)
}

えは変わらないのではないかと思われる。

なお，プラスチックへのメッキについて，知識を得た い方々のために参考文献を末昆に示し，本稿の不備を補 うことにした.

\section{2 化学メッキと電気メッキの併用による プラスチックヘのメッキ法}

現在, 最も広く用いられている方法で, 図 1 に示すよ うな手順で行なう。

射出成型された ABS 成型品は, 成型ひずみを除去す るために整面*を行なう，整面には熱風方式，温水浸せ き方式，整面液浸せき方式があるが，整面液方式が多く 使われている，脱脂产必要とするものは脱脂しエッチン グを行なう.エッチングには化学エッチングと機械エッ チングがあるが, 化学エッチングが主として使われてい る. 化学エッチングにより, ABS 表面の粗度が増し, この粗面にメッキが主として機械的に密着する.センシ タイジングは,粗化された ABS 面に二価の錫イオンを 吸着させることをいい，アクチベーションは，二価の錫 イオンを吸着した ABS を塩化パラジウムの盐酸々性 液に浸せきし，ABS 面に金属パラヂウムを析出させる ことをいう。

金属パラヂウムが析出した ABS を, 化学ニッケルメ ッキ液または化学銅メッキ液に浸せきすると，化学メッ キ反応が進行し，ABS 面はニッケルまたは 銅の皮膜で おおおれる。

この皮膜によって, ABS は電導性を持っことになり，

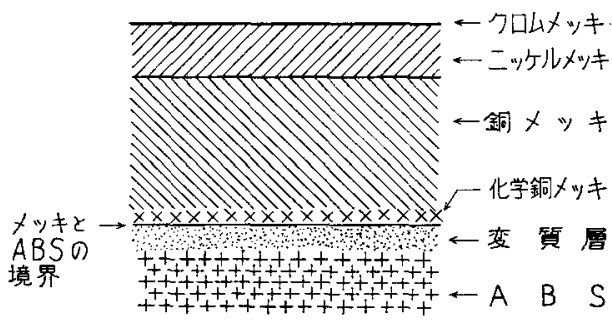

四 2 ABS プラスチックにメッキした ものの断面図

\footnotetext{
•プラスチックの成型品には成型ひずみ(残留心力)がある。これを除 去する工程を整面と呼ぶ．金屈製品の残嵧灾力を除去するのにアンニ

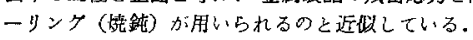


その上に電気メッキが行なわれる、電気メッキには普 通，銅，二ッケル，クロムの三層メッキが使われるの で, ABS の上にメッキしたものの断面は, 図 2 に示す ようである、銅メッキの厚さは、ニッケルメッキの厚さ の $2 \sim 3$ 倍とするのが普通である。

\section{ABS プラスチックヘのメッキ}

ABS はアクリロニトリル，ブタジェン，スチレンの 三者からできている・メッキに適する ABS の成分の一 例を示すと表1のようである. 主成分はスチレンでアク リロニトリルがこれに次ぎ，ブタジエンは 10〜20\% で

表 1 メッキ用 ABS プラスチックの成分の一例

\begin{tabular}{|c|c|c|c|}
\hline No. & 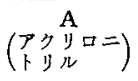 & $\begin{array}{c}S \\
(x \neq \nu \nu)\end{array}$ & $\begin{array}{c}\mathrm{B} \\
\text { (フタジェン) }\end{array}$ \\
\hline 1 & 25 & 65 & 10 \\
\hline 2 & 21 & 64 & 15 \\
\hline 3 & 24 & 60 & 16 \\
\hline 4 & 25 & 54 & 21 \\
\hline 5 & 25 & 61 & 14 \\
\hline 6 & 27 & 51 & 22 \\
\hline
\end{tabular}

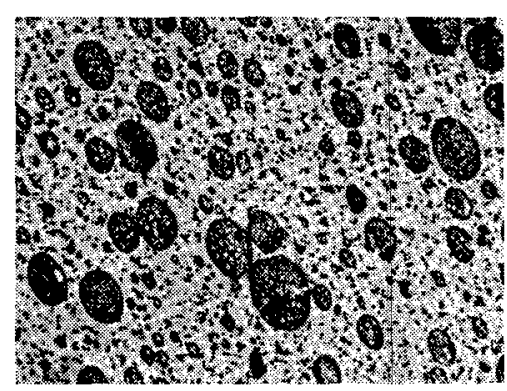

写真 1 ABS プラスチックの断面 $\times 10,000$

(ABS の超薄切片をつくり電子線を透過させて撮影)
ある。

ABS をウルトラミクロトームで超薄切片とし（厭さ $0.05 \mu$ 前後), オスミウム酸で染色してから電子顕微鏡 で組織を観察すると，写真1のようである，だ円体のも のが分散しているが，これはブタジエンである.ブタジ エンが方向性を持って配列しているのは，ABS を射出 成型したときの流れの方向を示している，成型ひするが 大きいときは，ブタジェンの形は写真 1 に見るよりもさ らに長軸方向にのびただ円体となり，成型ひずみが小さ いときは，球体に近くなる。

成型ひずみ除去しなければならず，除去できたか不 汃の判定は，承醋酸浸せき法が利用される，氷醋酸に浸 せきするとひずみの大きい部分には割れが，中程度の処 には白化が，小さい部分には割れも白化もあらわれな マ.

$\mathrm{ABS}$ をクロム酸, 硫酸, リン酸の混液中に浸せきし て化学エッチングすると，ABS の表面は写真 2 のよう になる.丸い穴が散在しているのは,ブタジエンが溶解し た溶解痕である．化学エッチング液によってブタジェン

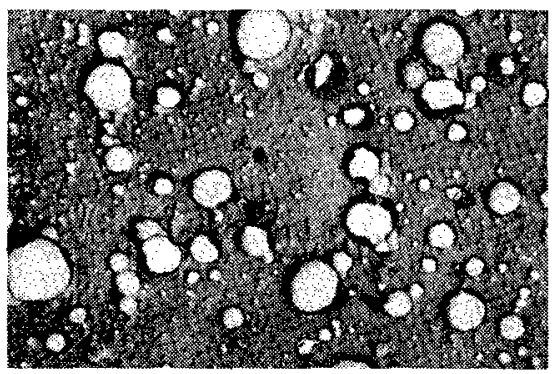

写真 2 ABS プラスチックを化学エッチングした 表面 (レプリカ法) $\times 10,000$

表 2 ABS を化学エッチングしたときにできるおう痕の大きさと数と面積

\begin{tabular}{|c|c|c|c|c|c|c|c|c|c|c|}
\hline $\begin{array}{l}\text { エッチンクの } \\
\text { 過不 足 }\end{array}$ & \multicolumn{4}{|c|}{ エッ $ォ ン ク ク$ 適 正 } & \multicolumn{4}{|c|}{$エ ッ チ ン \nsucc$ 不足 } & \multicolumn{2}{|c|}{ エッチング過度 } \\
\hline \multirow{2}{*}{ 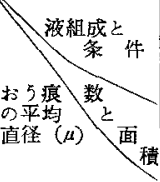 } & $\begin{array}{l}\text { 硫酸(比重 } \\
\text { 重ク口酸 } \\
50^{\circ} \mathrm{C} \text {, 水 }\end{array}$ & $\begin{array}{r}84) 100 \mathrm{cc} \\
15 \mathrm{~g} \\
50 \mathrm{cc} \\
5 \text { 分間 }\end{array}$ & $\begin{array}{l}\text { 左に } \\
50^{\circ} \mathrm{C} \text {, }\end{array}$ & $\begin{array}{l}\text { 同 } \begin{array}{l} \\
20 \text { 分䦓 }\end{array}\end{array}$ & 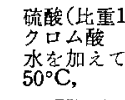 & .84) $\begin{array}{r}250 \mathrm{cc} \\
75 \mathrm{~g} \\
100 \mathrm{cc} \\
5 \text { 分間 }\end{array}$ & $\begin{array}{l}\text { 硫酸(比重1 } \\
\text { 重ク口酸 } \\
50^{\circ} \mathrm{C} \text {, }\end{array}$ & $\begin{array}{r}84) 100 \mathrm{cc} \\
15 \mathrm{~g} \\
50 \mathrm{cc} \\
30 \text { 秒間 }\end{array}$ & $\begin{array}{l}\text { 硫酸 (比重 } \\
ク \text { 口酸 } \\
\text { 水 } \\
50^{\circ} \mathrm{C}\end{array}$ & $\begin{array}{r}\text {.84) } 800 \mathrm{cc} \\
33 \mathrm{~g} \\
200 \mathrm{cc} \\
5 \text { 分間 }\end{array}$ \\
\hline & $\begin{array}{c}\text { おう瘏の数 } \\
\text { (個/ } \mathrm{cm}^{2} \text { ) }\end{array}$ & $\begin{array}{c}\text { 扛 } 5 \text { 澸の占 } \\
\text { め面積 } \\
(\%)\end{array}$ & $\begin{array}{c}\text { 出う痕の数 } \\
\left.\text { (個/ } \mathrm{cm}^{2}\right)\end{array}$ & $\begin{array}{c}\text { 去了漫口占 } \\
\text { 女西皘 } \\
\text { (\%) }\end{array}$ & $\begin{array}{c}\text { お5展の数 } \\
\left.\text { (個 } / \mathrm{cm}^{2}\right)\end{array}$ & $\begin{array}{c}\text { お疸の占 } \\
\text { める面樍 } \\
(\%)\end{array}$ & $\begin{array}{c}お う \text { 浪の数 } \\
\left(\text { (個 } / \mathrm{cm}^{2}\right)\end{array}$ & $\begin{array}{c}\text { お5缐の占 } \\
\text { める積 } \\
(\%)\end{array}$ & $\begin{array}{c}\text { おう痕の数 } \\
\left.\text { (個 } / \mathrm{cm}^{2}\right)\end{array}$ & 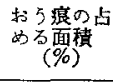 \\
\hline & 1 & 0.78 & 1 & 0.93 & 0 & 0 & 2 & 1.85 & & \\
\hline $1.8 \sim 2$ & 0 & 0 & 2 & 1.68 & 0 & 0 & 1 & 0.84 & & \\
\hline $1.6 \sim 1.8$ & 1 & 0.56 & 3 & 2.00 & 1 & 0.56 & 1 & 0.67 & $i$ & \\
\hline $1.4 \sim 1.6$ & 8 & 3.48 & 2 & 1.04 & 1 & 0.44 & 2 & 1.04 & & \\
\hline $1.2 \sim 1.4$ & 6 & 1.95 & 7 & 2.73 & 1 & 0.33 & 1 & 0.40 & & \\
\hline $1.0 \sim 1.2$ & 9 & 2.09 & 7 & 1.95 & 3 & 0.70 & 6 & 1.66 & & \\
\hline $0.8 \sim 1.0$ & 16 & 2.49 & 13 & 2.42 & 7 & 1.09 & 12 & 2.23 & & 5 \\
\hline $0.6 \sim 0.8$ & 77 & 7.22 & 21 & 2.35 & 17 & 1.59 & 16 & 1.80 & & \\
\hline $0.4 \sim 0.6$ & 128 & 6.00 & 37 & 2.07 & 38 & 1.78 & 40 & 2.24 & & E \\
\hline $0.2 \sim 0.4$ & 140 & 2.08 & 277 & 4.90 & 72 & 1.07 & 85 & 1.51 & & \\
\hline $0.2 \sim$ 以下 & 784 & 5.82 & 920 & 8.13 & 275 & 2.04 & 732 & 6.48 & & \\
\hline 合 & 1170 & 32.47 & 1290 & 32.20 & 415 & 9.60 & 898 & 20.78 & & \\
\hline
\end{tabular}


は優先的に溶解し、アクリロニトリルとスチレンは反応 をおこさない.しかし，エッチング時間が長くなれば， アクリロニトリルも作用を受ける．アクリロニトリルま で作用を受けた場合はオーバーエッチングでこの上への メッキの密着力は著しく低下する.

化学エッチングにより，ABS が化学的にどのように 変化するかということは，赤外吸収曲線により検討する ことができる。

表 2 は，ABS を化学エッチングしたときにできるお ら痕の大きさと数と面積を測定したもので, エッチング 適正の場合には, 直径 $0.2 \sim 2 \mu$ 前後のおう痕が $1 \mathrm{~cm}^{2}$ に 1000 個以上できている.

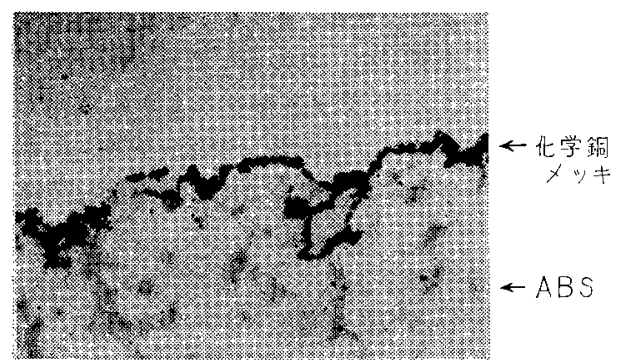

写真 3 ABS プラステックヘの化学銅メッキ の析出状況 $\times 7500$ (超薄切片をつく り電子線を透過させて撮影)

写真 3 は, 化学エッチング後, 化学銅メッキを行なっ たものをウルトラミクロトームで $0.05 \mu$ 前後の厚さに 切り, 電子顕微鏡で化学銅メッキの付着状况を撮影した むのである.化学銅メッキは, 化学エッチングでできた 溶解痕の中にまで入り込み, ABS とメッキを主として 機械的に結合させている状況がよくあらわれている。

ABS とメッキの密着力を測定するには，いくつかの 方法があるが，最も広く利用されている方法は，ヒー トサイクルテストである.この方法はたとえばメッキ した ABS を $80^{\circ} \mathrm{C}$ に 1 時間保持し,これを室温中に 移して 30 分間放冷後, $-30^{\circ} \mathrm{C}$ に 1 時間保持してか ら再び室温中に移して 30 分間放冷することを 1 サ1 クルとする方法で, 高温 $\rightarrow$ 室温 $\rightarrow$ 低温 $\rightarrow$ 室温のサイク ルを繰り返すことによって、メッキの密着力を判断し ている. 密着力の弱いものは, 1 サイクルでメッキが

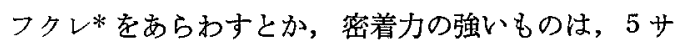
イクルでをフクレをあらわさないとかといことになる。

この方法は現場的であるから，最も広く利用されて いるが, ABS とメッキがいかなる強さで密着してい るかを知ることができないので，研究室ではピーリング テストが用いられている。

ピーリングテストは, 現品では困難なので, 図 3 に示

*ヒートサイクルテストを橾り返し行なうりメッキはプラステックか ら部分的心離れ，外観上，ふくれあがったように見充る。これをつク レと呼ひフクレのあらわれたものは不合格となる。

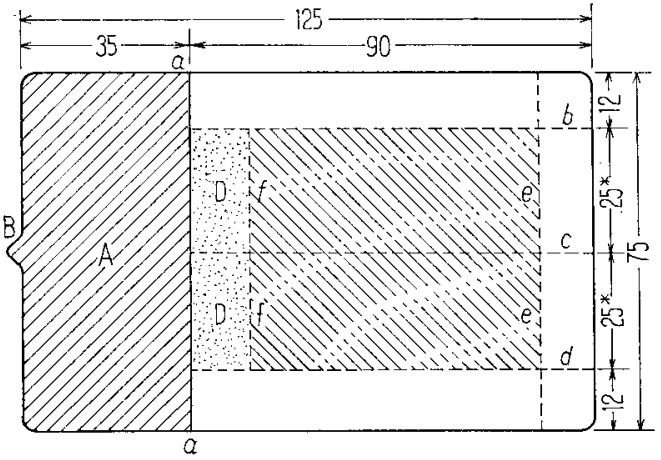

○Aの部分 (ハッチンクレルところ) は切り捨てる

OBはダートである

○点楾のとこらにメッキからプラスホックに達する切り迅み を入机る

○Dの部分（点々のとこら）はメッキをプラスチックからは がし,特然なテーブとつなくところ

○破線のところがヒーリング詿験をするとこうで,一枚の試 駼片で, 試験は 2 回できる

○水の上ころの寸法は切り込及を入れた後の寸法

図 3 ピーリング試験用試験片の一例 (単位 $\mathrm{mm}$ )

すようなテストピースをつくって行なわれる：このテス トピースにメッキを行ない,メッキを ABS からはく離 するために必要な力を測定するのである.

メッキは銅メッキまでで止め, ニッケル，クロムメッ キは行なわない方がテストしやすい. 銅メッキは柔㳄で あるが，ニッケル，クロムメッキは柔軟性に乏しく，は く離しにくいからである。

メッキを ABS からはく離するには，普通，オートグ ラフを使用する.オートグラフを使用するには，図 3 に 示すテストピースを装着する特殊な治具をつくらなけれ ばならない.また,メッキは常に ABS 面に対して, 直 角方向にはく離されるような治具でなければならない．

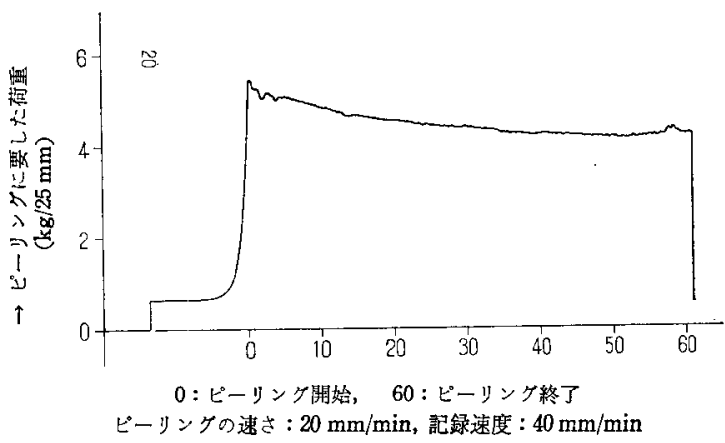

図 4 ピーリングテスト曲線（オートグラフ使用）

図 4 は，ピーリングテストを行なったときの曲線でめ る.この曲線はオートグラフ付属の自記装置から得られ たものである.密着力は $\mathrm{kg} / 25 \mathrm{~mm}$ で示される. $25 \mathrm{~mm}$ というのは，図 3 に示したメッキの愊である。はく離す るメッキの幅を $25 \mathrm{~mm}$ とする場合と，10 $\mathrm{mm}$ とする 場合があるが, $10 \mathrm{~mm}$ の場合は, $\mathrm{kg} / 10 \mathrm{~mm}$ で密着力 
があらわされる。

図 4 の場合は $4 \sim 5 \mathrm{~kg} / 25 \mathrm{~mm}$ の密着力であるが, 現 在のメッキ技術で得られている $\mathrm{ABS}$ とメッキの密着 力としては普通の值である. 密着力が弱い場合は, 1.5 $\sim 2.0 \mathrm{~kg} / 25 \mathrm{~mm}$ の場合もある。

金属の上のメッキの密着力をピーリングテストで測定 することは，まったく行なわれていない，その理由は， このような方法でテストできるほと，金属の上のメッキ は簡単にはく離しないからである、このことからむ,プ ラスチックへのメッキの密着力は, 金属の上へのメッキ の密着力におよばないことがわかる.

金属の上へのメッキの場合は，外観美，メッキ厚さ， 耐食性, 硬度, 耐摩耗性などがテストの項目にあげられ ているが，密着力がテストの対象になっていることはほ とんどない.プラスチックへのメッキの場合は, 密着力 が最重要のテスト項目にあげられているのは，プラスチ ックに密着のよいメッキを得ることがそれほど容易でな いことを示している。

プラスチックとメッキとの密着力を支配する因子には ,プラスチックの組成, 成型ひずみの大小, デザィンの 良否, 成型条件などメッキ技術以外の要素が非常に多い ので，メッキ技術の研究を進めるだけでは不十分で，プ ラスチックメーカー, 成型業者,メッキ業者の緊密な情

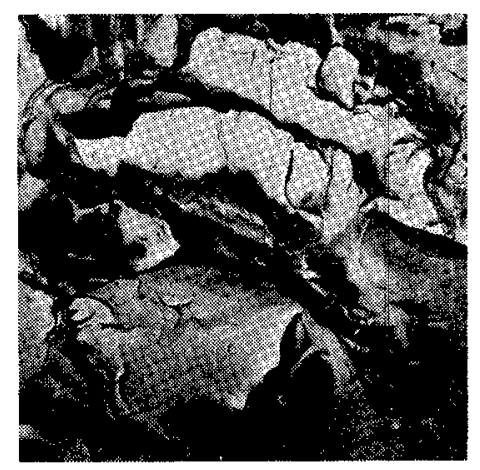

写真 4 ABS プラスチックを液体ホーニング （\$250）で粗化した状沉 (レプリカ) $\times 7500$

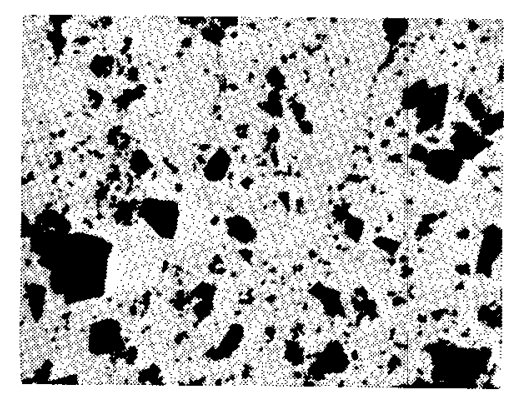

写真 5 メッキ用ポリプロピレン (集社開発)の 粗織 $\times 7500$ (超薄切片をつくり電子線を 透過させて撮影)
報交換が必要であるのみならず，デザイナーにも，メッ キしやすいデザインについて考慮してほしいのである.

化学エッチングの外に機械エッチングがあることは， 図 1 に示したが, 機械エッチングは主として液体ホーニ ングによって行なわれるので, ABS を液体ホーニング した場合の表面の状沉を写真 4 に示した. 大きく粗化さ れるので，この上にメッキを相当厚くつけても粗度は消 失しにくく，外観美が劣るので，メッキしたものに商品 価值がない．このために，機械エッチングはほとんど使 われていない.

\section{4 ポリプロピレンへのメッキ}

ポリプロピレンは，ABS よりも安価で，耐熱性がす ぐれている.したがって，この上に密着のよいメッキが 得られるならば, ABS にメッキするよりも有利である と考えられるが, ポリプロピレンには, ABS の中のB のような役割を果すものがないので, 技術的に問題があ った.

ポリプロピレンにメッキするカ法は二つある.一つは 現在市販されているもの（普通グレードと呼ぶ）にメッ キをつける方法で, 化学エッチングを二段に行なうのが 特徴である. 他の一つは,メッキ用ポリプロピレン(メ ッキグレードと呼ぶ）を開発し，ABS の上にメッキす る方法とあまり変わらない方法で密着のよいメッキを得 ようとするすのである. 日本では, 主として後者の方法 の研究が進んでいる.

写真 5 は，某ポリプロピレンメーカーが開発中のメッ キ用ポリプロピレンを $0.05 \mu$ 前後の薄片とし, 電子顕 微鏡で組織を撮影したものである、ポリプロピレンその ものであれば, 電子線は全面を透過するので白一色にな るはずであるが，黒いものが散在しているのは，ポリプ ロピレンの中に異物を添加しているためである。

この異物はメッキ用ポリプロピレンを開発中の各社に よってそれぞれ異なっているが, ABS を化学エッチン グするときに使用する化学エッチング液により, エッチ ングされるものである点は共通している.

写真 6 は, 写真 5 に示租織のポリプロピレン希クロ

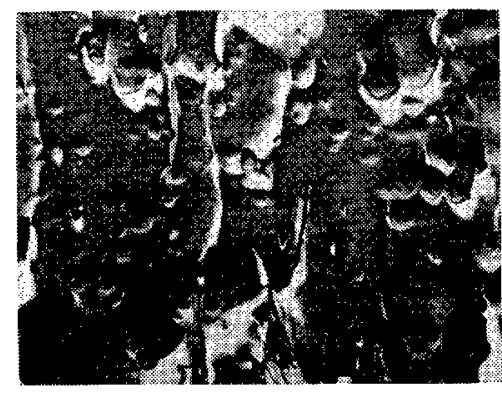

写真 6 写真 5 のポリプロピレンを化学エッ チングした面 (レプリカ) $\times 7500$ 
ム酸, 硫酸, リン酸系の化学エッチング液中に浸せき後 の表面状況を示している.ABS を化学エッチングした 写真 2 と比較すると，エッチング状沉はかなり異なる が, おう痕が多数散在している点は似ている.

ポリプロピレンには ABS 中のSに相当するものがな いので, 故意にSに相当する物質を添加し, 化学エッチ ングされやすいようにしメッキはエッチングによって できた㧍ら痕と主として機械的に密着するようにしてい る.

このようなポリプロピレンにメッキすると ABS の場 合よりも密着のよいメッキが得られることがわかってい るが，ポリプロピレンの上へのメッキの工業化を抽くら せている原因がまだ外にも㟧る。

メッキ用ポリプロピレンは普通のポリプロピレンより も高価になること，成型費は ABS の成型費よりも高い こと，成型によるヒケ*が ABS よりも著しいこと，ポ リプロピレン成型物は変形しやすいことなどがそれであ る.

\section{5 その他のプラスチックヘのメッキ}

フッ素樹脂，デルリン，セルコンなどへのメッキも海 外においては研究されている.エッチング方法もフッ素 樹脂に対しては金属ナトリウムが多く利用され，コロナ 放電や放射線の照射も試みられている，デルリン，セル コンにはパラトルエンスルホン酸, パークロールエチレ ン、ジオキサンの混液がエッチング剂として報告されて

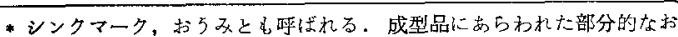

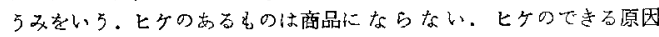
は、プラスチックの種類，成型機や金型の良否にもかるが，成型技術 に主こして支配される。
いる.

\section{文献}

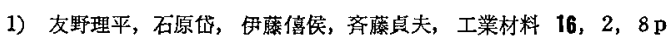
(Feb. 1968).

2)友野埋平, 吕戍長, 川島利夫, 岩沙昌一, 藤武春雄, 船田清荸, 藤井 金, 水上克之, 池上却寿, 右精之助, 村田 信, 井上雅章, 尾淚平次郎, オールプラステックス 9，4，1p (Mar. 1967).

3）友野理平，金属表面技術 16，1，18 p (Jan. 1965).

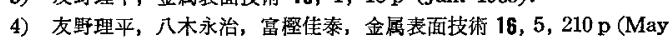
1965).

5)发野理平，高分子加工 15，9，9p (Sept. 1966).

6) 发野理平, 化学工業 (Nov. 1964).

7) 加藤訔一，ブラスチックス 18, 4,5,6 (Apr. May. June 1967).

8) 佐久間虎光，日本接着㙝会誌 3，3，29 p (Mar. 1967).

9）小西三郎，佐久間虎光，友野理平，小林義弘，嘏内 光，大阪府綜 合科学技術委員会プラスチック上へのメッキ分科会資料（1968 年 3 月).

10) 友野理平，プラスチックメッキ実務就本（1969 年）オーム社.

11) M. Narcus, (Reinhold Pul Corp., New York, 1960).

12) M. Muller, D. Baudrand, Plating ABS plastics (Robert Draper Ltd., Engrand, 1967).

13) W. Goldie, Electroplating and Metal Finishing 18, 12, 414 p (Dec. 1965) ; 19, 1, 2, 3, 4, 5 (Jan. Feb. Mar. Apr. May 1966).

14) D.W. Baudrand, Electroplating and Metal Finishing 20, 1, 2 p (Jan. 1967).

15) J. Freeman, D. Waston, Products Finishing, 51 (Aug. 1966).

16) G.H. Poll, Products Finishing, 50 (Feb. 1967).

17) E.A. Blount, Produch Finishing, 52 (Nov. 1965).

18) "Metallising plastics : A Commentary' on the Plastics instiute syposiun by our own correspondent" Electroplating and Metal Finishing 19, 12, 438 p (Dec. 1966).

19) "Plating of ABS Plastics: A symposium organised by Roto-Finish Limited" Electroplating and Metal Finishing 19, 11, $410 \mathrm{p}$ (Nov. 1966).

20) "Plating on plastics : Riedel process in use at Addy Products Limited" Electroplating and Metal Finishing 18, 10, $342 \mathrm{p}$ (Oct. 1965).

21) "Plating on polysulfone plastics" Products Finishing, $72 \mathrm{p}$ (August, 1968). 